\title{
GAGASAN W.S. RENDRA TENTANG SISTEM PENDIDIKAN INDONESIA: RESISTENSI TERHADAP SISTEM PENDIDIKAN KEKUASAAN ORDE BARU
}

\author{
Umi Salamah $^{1}$ \\ umi.salamah@budiutomomalang.ac.id
}

\begin{abstract}
Abstrak
Gagasan W.S. Rendra tentang pendidikan merupakan wujud keprihatinan terhadap carut-marutnya pendidikan akibat sistem pendidikan penyeragaman dan kepatuhan oleh kekuasaan Orde Baru. Teori yang mendasari kajian ini adalah teori hegemoni Gramsci, sedangkan metode analisisnya menggunakan analisis wacana kritis Michel Foucault. Sumber data berupa semua karya W.S. Rendra termasuk dialog dan pidato kebuayaannya. Berdasarkan analisis data disimpulkan bahwa gagasan sistem pendidikan W.S. Rendra adalah sistem pendidikan yang berkebudayaan Indonesia, yaitu pendidikan yang berbasis riset, lingkungan, humanis, sejarah, dan kebudyaan. Melalui riset, pendidikan membiasakan peserta didik untuk menghormati fakta objektif dan hukum alam. Melalui pemahaman potensi dan masalah di lingkungannya, membiasakan peserta didik untuk belajar mengatasi masalah-masalah faktual yang ada di lingkungannya. Melalui pemahaman nilai-nilai humanis, melatih kepekaan peserta didik terhadap ketidakadilan dan kekerasan kemanusiaan. Melalui pemahaman sejarah, memberikan semangat nasionalisme dan menghargai pahlawan bangsa. Melalui kebudayaan, mengokohkan kepribadian dalam kebudayaan sendiri. Gagasan W.S. Rendra tersebut relevan dengan cita-cita pendidikan dalam preambul dan pasal 31 UUD 1945, yaitu "mencerdaskan kehidupan bangsa" melalui pendidikan yang berkarakter Pancasila dan tidak memisahkan peserta didik dengan lingkungannya.
\end{abstract}

Kata kunci: sistem pendidikan, penyeragaman dan kepatuhan, resistensi Orde Baru, gagasan W.S. Rendra

\section{INSIGHT W.S. RENDRA ABOUT THE INDONESIAN EDUCATION SYSTEM: THE RESISTANCETO EDUCATION SYSTEM THE POWER OF THE NEW ORDER}

\begin{abstract}
The W.S. Rendra;s idea about education was a form of concern for the chaos of education due to education's system of Uniformity and obedience by the Orde Baru's power. The riset base on the Gramsci's theory of hegemony, while the analytical method uses Michel Foucault's critical discourse analysis. The data sources form of all works of the WS. Rendra includes his dialogue and cultural

\footnotetext{
${ }^{1}$ Dr. Umi Salamah, M.Pd, dosen tetap di Jurusan Pendidikan Bahasa dan Sastra IKIP Budi Utomo dan mengajar di MKU Universitas Brawijaya Malang. Saat ini, dia bersama para pegiat riset budaya sedang mengelola lembaga riset swasta yang diberi nama Nusantara Culture Akademy (NCA).
} 
speech. Based on the data analysis, was found the idea of the WS education system. Rendra is an education system that has Indonesian culture, namely education based on research, environment, humanity, history, and culture. Through research base, education get used students for to respect to objective facts and natural law. Through understanding potential and their sosial environment problems, educations get used students for to learn to solve of the factual problems that exist in their environment. Through understanding humanist values, educations get used students for to train their sensitivity to humanitarian injustice and violence. Through understanding Indonesian's history, giving a spirit of nationalism and respecting national heroes. Through culture, educations get used students for to strengthen personality in one's own culture. The Rendra's educational idea is relevant to the ideals of education in the preamble and article 31 of the 1945 Constitution, namely "improved the nation's intelligence" through education that is characterized by Pancasila and not to separate students from their environment.

Keywords: education system, uniformity and obedience, resistance to Orde Baru's power, W.S Rendra's ideas

\section{PENDAHULUAN}

SISTEM

PENDIDIKAN

HEGEMONI

KEKUASAAN

\section{ORDE BARU}

\section{Pendidikan}

seharusnya

menjadi tolok ukur tingkat

kemakmuran, kesejahteraan, dan

kemajuan peradaban suatu bangsa.

Akan tetapi, di era kekuasaan Orde

Baru, pendidikan justru berubah

menjadi alat hegemoni kekuasaan

(Haryono, 2006; McGlynn, 2007).

W.S. Rendra menggambarkan fakta

kemunduran sistem penyelenggaraan

pendidikan oleh Kekuasaan Orde

Baru, antara lain pada "Sajak Anak

Muda" berikut ini:

Kita adalah angkatan gagap... inilah gambaran rata-rata pemuda tamatan SLA, pemuda menjelang dewasa.
Dasar pendidikan kita adalah kepatuhan. Bukan pertukaran pikiran.

Ilmu sekolah adalah ilmu hafalan, dan bukan ilmu latihan menguraikan.

Dasar keadilan di dalam pergaulan,

serta pengetahuan akan kelakuan manusia,...

tidak dianggap sebagai ilmu yang perlu dikaji dan diuji.

Kenyataan di dunia menjadi remang-remang.

Gejala-gejala yang muncul lalu lalang, tidak bisa kita hubunghubungkan.

Kita marah pada diri sendiri

Kita sebal terhadap masa depan. Lalu akhirnya, menikmati masa bodoh dan santai.

Di dalam kegagapan, kita hanya bisa membeli dan memakai tanpa bisa mencipta.

Kita tidak bisa memimpin, tetapi hanya bisa berkuasa, persis seperti bapak-bapak kita. Kita adalah angkatan gagap. Yang diperanakan oleh angkatan kurangajar.

Daya hidup telah diganti oleh 
nafsu.

Pencerahan telah diganti oleh

pembatasan.

Kita adalah angkatan yang

berbahaya.

(Rendra, 1980).

Wacana dalam puisi di atas, menggambarkan sikap W.S. Rendra yang menolak sistem pendidikan penyeragaman dan kepatuhan/ indoktrinasi. Menurutnya, sistem tersebut telah mengakibatkan pendidikan makin carut-marut dan tidak berkepribadian. Peserta didik menjadi robot yang hanya bisa menghafal namun tidak kritis, tidak percaya diri, dan tidak peka. Peserta didik hanya dibiasakan menghafal materi dan rumus-rumus asing yang tidak dapat digunakan untuk menyelesaikan masalah kehidupan di lingkungannya.Latihan menguraikan, logika kritis-analitis, dasar keadilan, dan pengetahuan kepribadian manusia dianggap sebagai ilmu yang tidak perlu diajarkan di sekolah. Akibatnya, peserta didik menjadi gagap, penakut, psimis, tidak peka, tidak acuh terhadap masalah kemanusiaan dan ketidakkeadilan, dan tidak mampu mengenali kepribadian orang di sekitarnya. Generasi yang dihasilkan oleh sistem pendidikan seperti ini menurut W.S.
Rendra tidak akan berkontribusi dalam pembangunan peradaban yang lebih maju (Rendra, 1983; Salamah, 2017).

Pendidikan penyeragaman dan kepatuhan di masa Orba hanya menghasilkan disiplin ilmu yang semu dan melahirkan generasi yang latah, oportunis, hedonis, tidak peduli pada lingkungan. Generasi yang dihasilkan memiliki nation character sangat rendah karena pendidikan tidak berisi kebudayaan Indonesia. Pendidikan seperti menghasilkan genarasi yang mudah dipencundangi dan sangat berbahaya bagi kedaulatan dan kemajuan peradaban masa depan bangsa (Salamah, 2017).

Fakta tentang kuatnya hegemoni kekuasaan dengan indoktrinasi militeristik terhadap pendidikan dan daya kritis mahasiswa juga disampaikan oleh W.S. Rendra melalui "Sajak Pamplet Cinta" sebagai berikut: aku melihat wajah-wajah berdarah para mahasiswa. Kampus telah diserbu mobil berlapis baja. Kata-kata telah dilawan dengan senjata.

Aku muak dengan gaya keamanan semacam ini.

Kenapa keamanan justru 
menciptakan ketakutan dan

ketegangan

Sumber keamanan seharusnya

hukum dan akal sehat.

Keamanan yang berdasarkan

senjata dan kekuasaan adalah

penindasan (Rendra, 1980).

Melalui puisi di atas, W.S. Rendra menyatakan sikap keprihatianannya terhadap kenyataan sosial dalam penyelenggaraan pendidikan yang sarat dengan campur tangan militer. Militer yang seharusnya melindungi rakyat, berubah fungsi menjadi alat kekuasaan yang bertindak represif terhadap mahasiswa atas nama menjaga stabilitas nasional. Mahasiswa yang bersikap kritis terhadap kebijakan pemerintah, justru diintimidasi, diancam, diculik, disiksa, dan dituduh subversi. Tindakan represif kepada mahasiswa dimaksudkan agar mahasiswa takut dan patuh terhadap semua keputusan dan kebijakan dari kekuasaan Orde Baru (Salamah, 2017). Hal itu menunjukkan bahwa indoktrinasi dengan militerisasi di dalam kampus tidak sekedar membatasi daya kritis, tetapi membungkam daya kritis mahasiswa. Cara-cara represif tersebut berakibat meruntuhkan daya hidup, daya gerak, daya kreatif, dan daya produktif mahasiswa. Akibat jangka panjang dari sistem pendidikan Orba, adalah generasi terdidik yang hanya siap menjadi pegawai daripada pelaku usaha/interpreneurship. Mentalitas telah dibentuk sebagai pegawai yang patuh dan tunduk kepada atasan, bukan pegawai yang kreatif dan produktif.

Lebih lanjut, W.S. Rendra menyampaikan fakta pendidikan yang hanya berorientasi pada buku teks dalam kutipan puisi "Sajak Seonggok Jagung Di Kamar" berikut ini. “

... Seonggok jagung di kamar dan seorang pemuda tamat SLA. Tak ada uang, tak bisa menjadi mahasiswa. Hanya ada seonggok jagung di kamarnya. Ia memandang jagung itu dan ia melihat dirinya terlunta-lunta. Ia melihat dirinya ditendang dari diskotik. Ia melihat sepasang sepatu kenes di balik etalase. Ia melihat saingannya naik sepeda motor. Ia melihat nomor-nomor lotre. Ia melihat dirinya sendiri miskin dan gagal. Seonggok jagung di kamar tidak menyangkut pada akal, tidak akan menolongnya. Seonggok jagung di kamar tak akan menolong seorang pemuda yang pandangan hidupnya berasal dari buku, dan tidak dari kehidupan. Yang tidak terlatih dalam metode, dan hanya penuh hafalan Pendidikan telah 
memisahkannya dari kehidupan... Aku bertanya: Apakah gunanya pendidikan bila hanya akan membuat seseorang menjadi asing di tengah kenyataan. Persoalannya? Apakah gunanya pendidikan bila hanya mendorong seseorang menjadi layang-layang di ibukota, kikuk pulang ke daerahnya? Apakah gunanya seseorang belajar filsafat, sastra, teknologi, ilmu kedokteran, atau apa saja, bila pada akhirnya, ketika ia pulang ke daerahnya, lalu berkata: " Di sini aku merasa asing dan sepi!" (Rendra, 1980: Seonggok Jagung Di Kamar).

Melalui kutipan puisi di atas, W.S. Rendra menyampaikan fakta akibat sistem pendidikan yang hanya berorientasi pada buku teks, hanya memberikan kecerdasan otak tetapi bukan kecerdasan hidup. Pendidikan justru menyebabkan peserta didik berpikiran sempit, miskin ide, dan minim keterampilan. Akibatnya, peserta didik tidak mengetahui cara mengatasi persoalan kehidupan dengan potensi yang dimiliki. Itulah sebabnya, ketika dihadapkan pada kekayaan lingkungan yang berlimpah, mereka hanya berpikir secara instan bagaimana menghasilkan uang secara cepat dengan menjual bahan mentah dengan harga yang murah.
Potensi lingkungan yang berlimpah, tidak memiliki makna ekonomi bagi generasi terdidik yang berasal dari pendidikan penyeragaman dan kepatuhan. Dalam puisi di atas, Rendra juga mempertanyakan apakah gunakanya pendidikan jika tidak mampu memberikan manfaat bagi lingkungan dan daerahnya.

Selanjutnya, W.S. Rendra juga menjelaskan sistem pendidikan di perguruan tinggi pafa masa Orde Baru yang disampaikan pada puisi "Sajak Tangan" berikut:

Inilah tangan seorang mahasiswa, tingkat sarjana muda. Tanganku. Astaga. Tangan di dalam kehidupan muncul di depanku. Tanganku aku sodorkan. Nampak asing di antara tangan beribu. Tanganku yang gamang tidak memecahkan persoalan. Aku bimbang akan masa depanku. Hidupku tanpa masa depan. Aku berjalan mengembara. Aku akan menulis kata-kata kotor di meja rektor (Rendra, 1980: Sajak Tangan)

Penggunaan ungkapan “Tanganku gamang tidak memecahkan persoalan, nampak asing di antara tangan beribu, dan aku bimbang tanpa masa depan" menggambarkan mahasiswa yang tidak dibekali keterampilan dan kecakapan hidup sehingga tidak 
mampu bersaing dalam dunia kerja, tidak mampu berpartisipasi mengelola kekayaan daerah, dan tidak mampu memecahkan persoalan di lingkungannya. Penggunaan ungkapan "Rektor dan Kata kotor", menggambarkan kekuasaan rektor yang mandul sebagai pimpinan perguruan tinggi, tidak memiliki inisiatif untuk memajukan pendidikan dan menyiapkan generasi yang berkualitas.

Melalui kutipan puisi di atas, W.S. Rendra menyampaikan sikap keprihatinannya terhadap sistem penyelenggaraan pendidikan tinggi yang tidak diimbangi dengan lembaga riset, mengakibatkan mahasiswa menjadi gagap mengaplikasikan teori sesuai dengan permasalahan yang dihadapi dalam realitas kehidupan. Mereka menjadi canggung dan ragu menghadapi dunia kerja. Mereka tidak memiliki rasa percaya diri karena tidak memiliki kecakapan hidup, sehingga tidak mampu bersaing di dunia kerja. Lembaga pendidikan hanya menghasilkan pengangguranpengangguran terdidik.

Melalui dialog Yose Karosta, dalam lakon Mastodon dan Burung
Kondor, W.S. Rendra juga menyampaikan fakta akibat pendidikan yang hanya berorientasi pada buku digambarkan dalam dialog Yose Karosta (tokoh pemikir pada naskah tersebut), sebagai berikut:

Ketika saya masih mahasiswa orang menasehati saya dengan keras, cepat-cepatlah lulus dengan baik-baik. Karena negara membutuhkan tenagamu. Omong kosong. Aku telah lulus dengan cepat, tapi nyatanya negara tidak bisa memberi kerja kepadaku. Negara ini semestinya mempunyai banyak lapangan kerja. Tetapi kenyataannya negara ini semakin sempit lapangan kerja (Rendra, 1973)

Penggunaan ungkapan "Cepat lulus, negara membutuhkan tenaga kerja, dan omong kosong" menggambarkan sikap prihatian dan muak terhadap sistem pendidikan penyeragaman yang hanya bertumpu pada buku teks yang diseragamkan. Mereka hanya diajari menghafal teori dan rumus-rumus asing tanpa mengetahui aplikasinya dalam kehidupan nyata. Mereka hanya cocok menjadi pegawai dan alat birokrasi "benalu" bagi negara (Rendra, 2004). Mereka dibayar oleh negara tanpa kerja yang profesional. Pada masa Orde baru, banyak dijumpai para pegawai dan birokrat 
yang menganggur, bermain-main, dan belanja menghabiskan uang negara (Salamah, 2017).

Lagi-lagi, W.S. Rendra menegaskan bahwa pendidikan penyeragaman dan kepatuhan tidak membekali kecakapan hidup dan hanya menyiapkan lulusan sebagai pegawai yang takut dan malas, bukan pegawati yang kreatif, produktif, inovatif. Pendidikan juga tidak menyiapkan lulusan yang siap sebagai pelaku usaha yang kreatif, peka, dan produktif membangun peradaban bangsanya. Sistem pendidikan semacam itu, juga hanya menghasilkan penguasa yang congkak, takut dikritik, psimis, dan kurang humanis, serta tidak mampu menghasilkan pemimpin yang humanis, humbel, terbuka, dan berpikiran progresif untuk pembangunan peradaban bangsa yang berdaulat dan bermartabat.

Untuk meredam gejolak perlawanan itu, sistem pendidikan yang berisi kebudayaan kapitallis itu, dilengkapi dengan sistem kepatuhan yang dikomando secara militer (Pilger, 2002), seperti yang terdapat dalam kutipan berikut ini.

... Ah, di dalam kemabukan, wajah berdarah akan terlihat sebagai bulan.---

Mengapa harus kita terima hidup begini?

Seseorang berhak diberi ijazah dokter, dianggap sebagai orang terpelajar, tanpa diuji pengetahuannya akan keadilan. Dan bila ada tirani merajalela, ia diam tidak bicara, kerjanya cuma menyuntik saja.

Bagaimana? Apakah kita akan terus diam saja.

Mahasiswa-mahasiswa ilmu hukum, dianggap sebagi bendera-bendera upacara, sementara hukum dikhianati berulang kali.

Mahasiswa-mahasiswa ilmu ekonomi dianggap bunga plastik, sementara ada kebangkrutan dan banyak korupsi. ...

Daya hidup telah diganti oleh nafsu.

Pencerahan telah diganti oleh pembatasan.... Apakah kita tidak dimaksud untuk mengerti itu semua? Pejambon, Jakarta, 23 Juni 1980 (Rendra, 1980).

Ungkapan

"Dalam

kemabukan, wajah berdarah akan terlihat seperti bulan" menggambarkab sikap muak dan prihatin W.S. Rendra terhadap sistem militer yang masuk ke dalam lembaga pendidikan dalam bentuk sistem kepatuhan. Dengan menerapkan sistem kepatuhan itu, mahasiswa yang bersikap kritis diculik, dipenjara, disiksa, dibunuh, 
dan dibuang (Rendra, 2001; Fatah, 2004). Demi melanggengkan kekuasaan, sistem tersebut dilaksanakan dengan kepongahan. Akibatnya, sistem pendidikan menjadi korban "pembisuan" yang melahirkan lulusan yang gagap, penakut, psimis, dan masa bodoh. ${ }^{2}$

Selanjutnya ungkapan "Mahasiswa kedokteran kerjanya hanya menyuntik saja, diam meski tirani merajalela karena tidak pernah diuji pengetahuan tentang keadilan" menggambarkan sikap W.S. Rendra yang sangat prihatin terhadap sistem pendidikan kepatuhan dan tidak mengajarkan dasar-dasar hukum dan kemanusiaan. Akibatnya, para peserta didik menjadi tak peduli terhadap pelanggaran kemanusiaan, dan takut membantu korban pelanggaran kemanusiaan dan keadilan.

Berikutnya ungkapan "Mahasiswa ilmu hukum dianggap sebagi bendera-bendera upacara, sementara hukum dikhianati berulang kali”. Ungkapan tersebut merupakan sikap muak dan prihatin

${ }^{2}$ Salamah, Umi. 2017. Perlawanan Simbolik W.S. Rendra terhadap Hegemoni Kekuasaan Orde Baru. Disertasi tidak diterbitkan. PPS Universitas Muhmmadiyah Malang.
W.S. Rendra terhadap sistem penyeragaman dan kepatuhan. Bahkan di Fakultas hukum yang seharusnya memiliki kepekaan terhadap berbagai kasus pelanggaran keadilan dan kemanusiaan, mahasiswa hanya bisa menghafal pasal-pasal KUHP produk penjajahan. Mereka tidak dilatih bersikap kritis-analitis terhadap relevansi pasal-pasal dalam KUHP yang ada selama ini. Mereka juga tidak dilatih peka terhadap permasalahan hukum di negaranya.

Pertanyaan "Mengapa harus kita terima hidup begini? Apakah kita akan terus diam saja. Daya hidup telah diganti oleh nafsu. Pencerahan telah diganti oleh pembatasan. Apakah kita tidak dimaksud untuk mengerti itu sетиа?" merupakan sikap kegelisahan dan keprihatinan W.S. Rendra untuk mengajak para pelaku dan pengambil kebijakan pendidikan sigap membenahi pendidikan. Pendidikan yang memberikan kecakapan hidup dan pencerahan bagi peserta didik, bukan kepatuhan yang menciptakan ketakutan dan menciptakan daya mati. 
Kegelisahan dan keprihatian

W.S. Rendra terhadap pendidikan budi pekerti juga dipotret dalam puisi "Sajak SLA" sebagai berikut:

...

Murid-murid mengobel klentit ibu gurunya Bagaimana itu mungkin? Itu mungkin.

Karena tidak ada patokan untuk apa saja. Semua boleh. Semua tidak boleh.

Tergantung pada cuaca.

Tergantung pada amarah dan girangnya sang raja.

Tergantung pada kuku-kuku garuda dalam mengatur kata-kata.... (Rendra, 1980)

Kutipan puisi di atas menggambarkan sikap murid yang tidak menghormati gurunya. Hal itu disebabkan oleh budaya materi yang merupakan salah satu unsur dari ideologi kapitalis. Budi pekerti yang menjadi unsur kebudayaan Indonesia (Kebudayan Timur pada umumnya) telah digantikan dengan budaya materi (Rendra, 2001; Fatah, 2004; Salamah, 2017). Hal itu juga merambah ke dunia pendidikan. Guru yang memiliki gaji sangat kecil pada saat itu menjadi bulan-bulanan murid dan orang tuanya. Para murid menghormati bukan karena ilmunya tetapi karena hartanya. Para guru pun tidak berani memberikan sansi budi pekerti kepada anak pemilik modal dan anak pejabat.
Berdasarkan analisis wacana kritis Michel Foucault, sistem pendidikan penyeragaman dan kepatuhan/indoktrinasi yang dilakukan oleh Orde Baru merupakan pandangan yang berakar pada ideologi kapitalis Barat di era teknologi industri 2.0. Meskipun teknologi industri 2.0 di Eropa berlangsung pada 1870-an dan berakhir pada awal abad 20 tepatnya pada tahun 1914, namun di Indonesia, industri 2.0 baru dimulai di awal era Orde Baru pada tahun 1970-an³ Pada masa awal Orde Baru, masuknya modal Kapitalis ke Indonesia sangat masif (Wood, 2013)). Sebagian besar sumber daya alam dan industri besar yang didirikan di Indonesia dikuasai oleh kapitalis atau pemilik modal dari asing terutama Amerika dan sekutinya, serta pribumi yang difasilitasi oleh Presiden Soeharto ${ }^{4}$. Kebijakan itu menyebabkan seluruh sistem penyelenggaraan negara

\footnotetext{
${ }^{3}$ Muntone, Stephanie. Second Industrial Revolution". Education.com. The McGrawHill Companies. Diakses tanggal 14 October 2013.

${ }^{4}$ Kwik Kian Gie. 2011. Pak Harto Salah Memilih Tim Ekonomi dan Pengambilan Kebijakannya. http://kwikkiangie.com/v1/2011/03/pakharto-salah-pilih-tim-ekonomi-dankebijakannya-artikel-2/
} 
diintervensi oleh pemilik modal (kapitalis) asing dan Bank Dunia. Pengaruh ideologi kapitalis dalam dunia pendidikan, mengakibatkan sistem pendidikan berisi kebudayaan kapitalis bukan kebudayaan Indonesia (Salamah, 2017). Akibatnya out put pendidikan dipersiapkan sebagai alat produksi industri kapitalis dan sebagian sebagai birokrat dan pegawai yang mempermudah operasional layanan kapitalis. Itulah sebabnya, buku teks pendidikan diseragamkan meskipun tidak sesuai dengan budaya dan potensi daerah.

\section{GAGASAN W.S. RENDRA TERHADAP SISTEM PENDIDIKAN DI INDONESIA}

Gagasan sistem pendidikan W.S. Rendra disampaikan secara tersurat dan tersirat dalam karyakaryanya. Gagasan yang disampaikan secara tersurat dapat dijelaskan melalui kutipan puisi dan dialog kebudayaan sebagai berikut.

Kita harus berhenti membeli rumus-rumus asing.

Diktat-diktat hanya boleh memberi metode, tetapi kita sendiri mesti merumuskan keadaan.

Kita mesti keluar ke jalan raya, keluar ke desa-desa,

mencatat sendiri semua gejala, dan menghayati persoalan yang nyata. (Rendra, 1980: Sajak Sebatang Lisong)

Kutipan puisi di atas merupakan gagasan pendidikan W.S. Rendra yang berbasis pada riset dan kebudayaan Indonesia. Ungkapan "Kita harus berhenti membeli rumusrumus asing" merupakan komitmen W.S Rendra terhadap kurikulum pendidikan yang harus berisi kebudayaan sendiri. Oleh karena itu, rumus-rumus membangun negara juga harus didasarkan pada potensi sumber daya alam dan potensi masyarakat Indonesia sendiri. Risetriset yang dilakukan dalam dunia pendidikan harus berbasis kearifan lokal dan potensi lingkungan. Kecanggiahan teknologi dan kebesaran peradaban yang dimiliki oleh bangsa Indonesia di masa lalu harus dirumuskan kembali sesuai dengan perkembangan IPTEK dan kebutuhan kekinian. Dengan cara tersebut maka, Indonesia akan mudah untuk mewujudkan kedaulatan dan kemandirian di segala bidang, serta ketangguhan dalam menghadapi arus globalisasi. Menurut W.S. Rendra, sejarah adalah 
tatabuku masa lalu (Rendra, 2004). ${ }^{5}$

Sebagai tata buku, sejarah menjediakan fakta objektif di masa lalu, baik berkaitan dengan kekayaan, potensi, keunggulan, maupun kelemahan bangsa di masa lalu. Bertolak dari pemahaman yang benar terhadap pengetahuan dan pengalaman sejarah sebagai tata buku, maka akan diperoleh rumusrumus kejayaan untuk membangun kemajuan peradaban bangsa dan dapat menghindari kesalahan yang menyebabkan keruntuhan suatu bangsa.

$$
\text { Selanjutnya ungkapan }
$$

"Diktat-diktat hanya boleh memberi metode" menekankan pada keprofesionalan dan kepiawaian guru dan dosen sebagai tenaga pendidik untuk mampu membumikan teori dari negara maju disesuaikan dengan potensi dan permasalahan masingmasing daerah di Indonesia. Pembumian teori asing dalam bentuk metode dimaksudkan agar teori asing tersebut diadaptasi, disederhanakan menjadi seperangkat langkah sistematis untuk bisa diterapkan/diaplikasikan oleh para

\footnotetext{
${ }^{5}$ Transkripsi wawancara kebudayaan di Q channel yang dipandu oleh peter $\mathrm{f}$. Ghonta (video 3, part 1, 2004)
}

peserta didik dalam melakukan riset terhadap potensi dan permasalahan faktual di daerah. Kata "Metode" merupakan kata kunci dari pembelajaran berbasis riset. Itulah sebabnya, para pendidik harus bisa menerjemahkan dan menyusun teori menjadi metode yang membumi. Dengan cara tersebut, peserta didik akan dibiasakan mengenal, memahami, menyelidiki, dan menemukan cara yang sesuai untuk membangun lingkungannya. Komitmen W.S. Rendra terhadap pendidikan berbasis riset dianjurkan diberikan sejak dini. Mulai pendidikan dasar, siswa harus dibiasakan melakukan riset dari yang sederhana atau tingkat dasar sampai tingkat lanjut.

Selanjutnya ungkapan "Kita mesti keluar ke jalan raya, keluar ke desa-desa, mencatat sendiri semua gejala, dan menghayati persoalan yang nyata tetapi kita sendiri mesti merumuskan keadaan" merupakan gagasan W.S. Rendra bahwa pendidikan harus membumi. Pendidikan tidak boleh memisahkan peserta didik dengan lingkungannya. Pendidikan tidak boleh hanya dilaksanakan di dalam kelas saja. 
Peserta didik harus dibiasakan untuk mengenal potensi dan permasalahan faktual lingkungannya agar memiliki kepekaan untuk menyelesaikan masalah di lingkungannya. Dengan kepekaan yang tinggi terhadap masalah dan potensi lingkungan, peserta didik akan memiliki sense of belonging untuk membangun dan menjaga daerahnya, dari penjamahan kaum kapitalis. Ini merupakan komitmen W.S. Rendra terhadap pendidikan kedaulatan bangsa.

Komitmen sistem pendidikan berbasis riset dan potensi lingkungan dalam puisi di atas dikuatkan oleh W.S. Rendra dalam dialog kebudayaan yang disiarkan oleh TV Channel sebagai berikut:

Sebagai orang modernis, saya percaya bahwa dalam Pendidikan, murid-murid itu harus diajari apa itu fakta objektif dan hukum alam. Fakta objektif itu adalah fakta yang senang atau tidak, tetapi itu ada, sedangkan hukum alam itu adalah peristiwa yang pasti terjadi di dunia dan sudah diatur oleh yang Mahakuasa. Apabila ada hukum alam yang dirusak oleh manusia, maka akan terjadi ketidaksetimbangan sehingga bisa menimbulkan bencana. Untuk itu, kita harus mencari kebenaran itu, anak didik itu harus dilatih untuk mencari fakta, dan menghormati fakta objektif ini. Kemudian dilatih untuk mengategorisasikannya, lalu menganalisanya, lalu menarik kesimpulan, lalu kemudian memverifikasikannya, ini sebenarnya adalah dasar dari sikap ilmiah/riset... sayangnya, di semua sekolah ini tidak ajarkan seperti itu (Rendra 2004)

Kutipan transkripsi dari dialog kebudayaan W.S. Rendra bersama Piter F. Gonta tersebut menunjukkan sikap dan komitmen yang kuat untuk menggagas sistem pendidikan yang bermakna bagi pembangunan peradaban dan memberikan bekal kecakapan hidup bagi peserta didik. Melalui kecakapan hidup, lulusan pendidikan dapat memiliki berbagai keterampilan dan pengetahuan untuk membangun daerahnya, sehingga berkontribusi dalam pembangunan peradaban yang lebih maju. Oleh karena itu, sejak pendidikan dasar, peserta didik harus dibiasakan untuk mengenal dan menghargai fakta objektif dan hukum alam. Cara menghargai fakta objekti dengan melatih peserta didik untuk mengumpulkan fakta,

\footnotetext{
${ }^{6}$ Transkripsi wawancara kebudayaan di Q Channel yang dipandu oleh Peter F. Ghonta (video 2, part 2, 2004)
} 
mengidentifikasi,

mengklasifikasi/mengategotikan, menganalisis, menyimpulkan, dan memverifikasi kebenaran fakta lalu membuat simpulan. Riset seperti itu, Rendra mnyebut sebagai The act of verification.

The act of verification $\mathrm{di}$ zaman Orba menurut W.S. Rendra (2004) tidak pernah diajarkan dalam pelaksanaan sistem pendidikan. Sehubungan dengan itu, Rendra memandang perlu menyampaikan gagasan sistem pendidikan yang seharusnya memihak kepada nilai-nilai budaya yang humanis dan berkemajuan sesuai dengan kebutuhan kekinian. Pendidikan mesti dekat dengan lingkungan agar peserta didik memiliki kecerdasan hidup (Rendra, 2004).

Gagasan yang disampaikan secara tersirat, antara lain dijelaskan melalui kutipan puisi "Sajak Anak Muda" berikut ini.

Apakah kita hanya dipersiapkan untuk menjadi alat saja?

Gelap. Pandanganku gelap.

Pendidikan tidak memberi pencerahan.

Latihan-latihan tidak memberi pekerjaan

Gelap. Keluh kesahku gelap.
Orang-orang hidup di dalam pengangguran.

Apakah yang terjadi di sekitarku ini? ...

Bagaimana? Apakah kita akan terus diam saja.

Daya hidup telah diganti oleh nafsu.

Pencerahan telah diganti oleh pembatasan....

Pejambon, Jakarta, 23 Juni 1980 (Rendra, 1980).

Penggunaan ungkapan "Pendidikan tidak memberi pencerahan. Latihan-latihan tidak memberi pekerjaan", yang didahului dengan kata gelap diulang dua kali mennyiratkan keingingan W.S. Rendra yang sangat besar terhadap sistem pendidikan yang memberikan pencerahan dan daya hidup kepada peserta didik. Pendidikan yang mencerahkan adal ah pendidikan yang memberikan latihan-latihan yang memberikan kecakapan hidup peserta didik, sehingga berguna bagi pengembangan potensi peserta didik. Pendidikan yang mencerahkan juga membekali dasar hukum dan kemunusiaan, etika dalam pergaulan, dan melatih logika dengan dasar ilmu filsafat untuk mengasah daya rasional. Adapun pendidikan yang membangkitkan daya hidup kepada peserta didik adalah pendidikan yang memberikan ruang seluas-luasnya 
dan mendorong peserta didik untuk berekspresi, kreatif, produktif, dan inovatif. Dengan pendidikan yang mencerahkan dan membangun daya hidup, peserta didik akan memiliki kepekaan dan terlatih untuk dapat berpartisipasi membangun dan menjaga potensi daerahnya

Pentingnya pendidikan berbasis pada potensi lingkungan juga disampaikan dalam kutipan puisi "Sajak Seonggok Jagung Di Kamar" berikut ini.

... Memandang jagung itu. Sang pemuda melihat ladang; ia melihat petani; ia melihat panen; dan suatu hari subuh, para wanita dengan gendongan pergi ke pasar .... Dan ia juga melihat gadis-gadis bercanda sambil menumbuk jagung menjadi maisena. Sedang di dalam dapur, tungku-tungku menyala, tercium aneka kuwe jagung. Seonggok jagung di kamar .... Ia siap menggarap jagung. Ia melihat kemungkinan otak dan tangan siap bekerja ... (Rendra, 1980)

Ungkapan "Seonggok jagung dikamar,.. Ia melihat kemungkinan otak dan tangan sisap bekerja" merupakan gagasan sistem pendidikan yang berbasis riset potensi lingkungan. Peserta didik dibiasakan melihat persoalan nyata tentang potensi melimpah yang dimiliki daerahnya dan tentang masalah yang dihadapi masyarakat dalam mengelola potensi daerahnya. Gambaran seorang pemuda melihat "Seonggok jagung di kamar" yang disertai dengan mengamati dan berlatih mengelola akan menumbuhkan sikap peka menciptakan lapangan kerja untuk dirinya dan masyarakat di lingkungannya. Dengan begitu, potensi lingkungan yang melimpah, memiliki makna ekonomi dan inovasi bagi peserta didik.

Selain itu, Rendra juga memiliki gagasan agar sistem pendidikan dapat membekali peserta didik mental yang tangguh dan pantang menyerah. Mental yang suka bekerja keras dan bekerja cerdas. Mental yang tahan banting, lapang dada/sabar, dan mampu mewujudkan kata-kata atau cita-citanya menjadi kenyataan melalui perjuangan yang gigih. Gagasan itu diungkapkan dalam puisinya yang berjudul "Paman Doblang" sebagai berikut:

Kesadaran adalah matahari. Kesabaran adalah bumi. Keberanian menjadi cakrawala. Dan perjuangan adalah perlaksanaan kata-kata. (Rendra, 1980)

Ungkapan "Kesadaran adalah matahari" merupakan gagasan sistem 
pendidikan yang mencerahkan dan memberi daya hidup, karena matahari adalah simbol dari energi penerangan dan daya hidup. Ungkapan "Kesabaran adalah bumi" merupakan gagasan sistem pendidikan yang mampu membekali peserta didik tahan banting, tidak mudah menyerah, berbakti kepada orang tua dan ibu pertiwi, karena "Bumi" selalu sabar, memberi dan tidak pernah mengeluh. Ungkapan "Keberanian menjadi cakrawala" merupakan gagasan bahwa pendidikan juga harus mampu membekali peserta didik dengan rasa percaya diri yang kuat dan keberanian yang besar dalam menghadapi persaingan dan tantangan global. Ungkapan "Perjuangan adalah perlaksanaan kata-kata" merupakan gagasan pendidikan membekali peserta didik semangat dan etos belajar keras untuk mewujudkan kata-kata dalam sikap, pikiran, dan tindakan nyata. "Pelaksanaan kata-kata" juga menggambarkan sikap konsistensi antara kata dan perbuatan, antara cita-cita dan perjuangan agar terwujud/tercapai.
Selain itu, W.S. Rendra juga menggagas dibangunnya karakter nasionalis yang disampaikan kutipan puisi sebagai berikut:

O, Sanjaya!

Leluhur dari kebudayaan tanah!

O, Purnawarman!

Leluhur dari kebudayaan air! Kedua wangsamu telah mampu mempersekutukan budaya tanah dan budaya air!

Tanah air O, Resi Kuturan! O, Resi Nirarta!...

Telah kamu ajarkan tatanan hidup yang aneka dan sejahtera, yang dijaga oleh dewan hukum adat.

O, Kajao Laliddo! ...Negarawan yang pintar dan bijaksana! Telah kamu ajarkan aturan permainan di dalam benturanbenturan keinginan yang berbagai ragam di dalam kehidupan:

Ade, bicara, rapang, dan wari.

Ialah adat, peradilan, yurisprudensi, dan pemerincian perkara

Yang di zaman itu di Eropa belum ada

Kode Napolean dua abad lagi baru dilahirkan

O, Erlangga ... dalam usia 17 tahun

Kau dorong rakyat di desa desa untuk menyempurnakan keadilan hukum adat mereka yang berbeda beda. Lalu kau perintahkan agar setiap adat mempunyai 40 prajurid adat yang menjaga berlakunya hukum adat, sehingga hukum adat menjadi adil, mandiri dan terkawal

Baru kemudian sesudah itu, Empu Baradah membantumu menciptakan hukum kerajaan 
Yang mempersatukan cara-cara kerjasama antara hukum adat yang berbeda beda

Sehingga penyair Tantular berseru, Bhineka Tunggal Ika Dengan puisi ini aku bersaksi bahwa hati nurani itu meski dibakar tidak bisa menjadi abu. Hatinurani senantiasa bisa bersemi, meski sudah ditebang putus di batang.

Begitulah fitrah manusia ciptaan Tuhan Yang maha Esa (Rendra, 1999)

\section{Penggunaan ungkapan}

"Wahai, para leluhur Nusantara..." merupakan gagasan pendidikan karakter nasionalis yang berbasis sejarah Nusantara. Ungkapan "Sanjaya sebagai kebudayaan tanah, Purnawarman sebagai kebudayaan air, Kajau Lalido sebagi ahli hukum, Airlangga sebagai ahli tata negara" mengingatkan bahwa tokoh-tokoh Nusantara adalah tokoh-tokoh yang lebih hebat dari bangsa Barat. Bahkan ketika Eropa masih berada di zaman kegelapan, Nusantara sudah memiliki tata pemerintahan, tata hukum, tata maritim, dan teknologi canggih seperti tata perairan (patirthan, candi, kapal penisi, dan lain sebagainya (Claessen, 1987; Yamin, 2011). Puisi ini merupakan gagasan W.S. Rendra di bidang pendidikan agar para ahli pendidikan lebih banyak mengkaji kebudayaan dalam perspektif sejarah Nusantara untuk menghargai kebudayaan bangsa sendiri. Dengan begitu, generasi terdidik dapat mengambil hikmah dan nilai-nilai dari tatabuku masa lalu. Dalam jangka panjang, peserta didik merasa bangga dan memiliki komitmen yang kuat untuk menjaga kedaulatan dan memajukan kebudayaan bangsa.

Kementerian pendidikan dan kebuadaan seharusnya berkolaborasi dengan para arkheolog, antropolog, sejarawan, dan sosiolog, untuk merumuskan pendidikan yang tepat bagi bangsa ini, yakni pendidikan yang berbasis kebudayaan sendiri, kerkemajuan, dan berkekinian. Hasil riset mereka tidak boleh hanya berhenti pada museum atau monumen saja, karena hakikat pendidikan adalah kebudayaan. Pendidikan tidak boleh hanya "menetek" ke negara donor karena tidak cocok dengan kepribadian dan kebutuhan bangsa dan negara sendiri dengan cara pandang masa kini. Menurut W.S. Rendra, sejarah harus kenalkan dan dipahamkan dengan cara yang menarik agar lulusan pendidikan dapat mengambil semangat sejarah 
untuk menghadapi peristiwa masa kini dan menyusun rencana masa depan (Salamah, 2017).

Ungkapan "Dengan puisi ini aku bersaksi bahwa hati nurani itu meski dibakar tidak bisa menjadi abu. Hatinurani senantiasa bisa bersemi, meski sudah ditebang putus di batang. Begitulah fitrah manusia ciptaan Tuhan Yang maha Esa" merupakan gagasan sistem pendidikan yang mengasah hati nurani, karena hati nurani tidak pernah mati. Ungkapan tersebut juga dapat menjadi pemicu bagi pemerhati, pelaku, dan pengambil kebijakan pendidikan agar optimis membenahi sistem penyelenggaraan pendidikan yang humanis, berkebudayaan, berkepribadian, berkemajuan, dan berkelanjutan karena hati nurani manusia senantiasa bersemi, meski sudah tertekan dalam waktu yang lama.

Gagasan W.S. Rendra terhadap pembangunan karakter nasionalis melalui sistem pendidikan juga disampaikan melalui puisi "Bandung Lautan Api" sebagai berikut:

Bagaimana mungkin kita bernegara Bila tidak mampu mempertahankan wilayahnya
Bagaimana mungkin kita berbangsa

Bila tidak mampu mempertahankan kepastian hidup bersama? Itulah sebabnya Kami tidak ikhlas menyerahkan Bandung kepada tentara Inggris..

(Rendra, 2004)

Pengenalan dan pemahaman sejarah perjuangan bangsa seharusnya memberikan ruang batin yang luas kepada anak didik untuk menghayati semangat, keberanian, dan tujuan para pahlawan memperjuangan kemerdekaan dan menjaga kedaulatan negara (Salamah, 2017). Ungkapan "Demi mempertahankan wilayah dan kepastian hidup, kami tidak ikhlas menyerahkan Bandung kepada tentara Inggris", merupakan cara mengasah semangat nasionalis melalui refleksi sejarah. Ungkapan itu merupakan semangat para pahlawan yang rela mati untuk mempertahankan kedaulatan negara dan martabat bangsa. Nilai-nilai semangat keberanian inilah yang sekarang mengalami degradasi dan perlu dibangun kembali. Dengan cara tersebut, secara sadar anak didik terbangun kesadaran dan semangat nasionalis untuk membela kedaulatan negara dan kepastian hidup bersama. 
Dengan cara tersebut semangat nasionalis dan patriotis terbangun secara mengakar.

Gagasan W.S. Rendra terhadap sistem pendidikan karakter nasionalis kepada peserta didik juga disampaikan oleh W.S. Rendra dalam dialog kebudayaan sebagai berikut:

Sebetulnya bangsa Indonesia itu karena habitatnya dan karena rahmat Allah, bisa membina kehidupan berbangsa, jauh-jauh hari. Artinya sebelum punya negara, sudah hidup berbangsa, dengan ciri-ciri sudah memiliki bahasa pergaulan sejak tahun 600-an. ...

Di Aceh ada penyair Hamzah Fansyuri menulis syair "Perahu" dan syair "Burung Balam" dalam bahasa melayu. Tidak karena dekrit raja. Padahal sudah ada sastra Aceh, sastra Arab, tetapi beliau banyak menulis syair "Perahu" dan "syair burung balam" dalam bahasa melayu yang indah, .... Fenomena yang aneh dan menarik juga bahwa Pada abad 19, peranakan Cina dan peranakan Indo Eropa, menulis sastra prosa kisah bersambung dengan bahasa Melayu. Koq nggak nulis dalam bahasa Cina atau bahasa Belanda?...Itu yang menganjurkan ya tentu pergaulan bersama...

Jadi pada tahun1928, para Pemuda yang bukan public figure, bukan pimpinan politik, bukan apa-apa. Mereka mengumumkan, Satu Tanah Air (karena belum punya Negara), Satu Bangsa, Satu Bahasa, dan satu Bahasa: Indonesia! Uiiiich, sekonyong-konyong Jong Java,
Jong Ambon, Jong Celebes lenyap. Semua organisasi pakai nama Indonesia, semua partai politik pakai identifikasi Indonesia. ... Itu karena rasa kebersamaan. Ini yang disebut Rasa Berbangsa! Jadi rasa berbangsa itu sudah ada, dan sampai sekarang ini malah makin kuat (Rendra, 2004).

Penggunaan simbol

"Pergaulan bersama, rasa berbangsa, dan rasa kebersamaan" menggambarkan adanya satu kesamaan kepentingan yang besar dari beragam kepentingan dan beragam budaya. Ungkapan tersebut merupakan ungkapan dari nilai gotong royong guyup-rukun, berBhineka Tunggal Ika Tan Hana Dharma Mangrwa yang dieksplorasi dari kebudyaan Nusantara (Claessen, 1987; Koentjaraningrat, 1994). Kekuatan tekat menghargai perbedaan, telah mampu menyatukan bangsa ini melalui produk budaya berupa bahasa Indonesia. Jadi sebenarnya rasa nasionalisme bangsa sudah ada sejak Indonesia belum merdeka. Jiwa nasionalis dalam perspektif sejarah tidak dibangun oleh sistem militer dalam bentuk kepatuhan dan penyeragaman, juga bukan oleh publik figur, melainkan oleh orang-orang sipil yang memiliki tujuan bersama, yakni lepas dari 
segala bentuk penjajahan. Jiwa nasionalis tersebut terajut melalui pergaulan bersama (bahasa Indonesia) dan kepentingan bersama (untuk merdeka). Nilai-nilai ini sangat penting untuk ditanamkan kepada peserta didik agar memiliki jiwa nasionalisme yang kuat untuk menjaga dan mempertahankan kedaulatan negara, serta tidak mudah terprovokasi oleh kepentingan dari luar. Gagasan ini menegaskan pentingnya pembelajaran nilai-nilai multikultur melalui pendidikan.

\section{SIMPULAN}

Gagasan sistem pendidikan yang disampaikan oleh W.S. Rendra merupakan bentuk resistensi terhadap sistem pendidikan yang dijalankan oleh kekuasaan Orde Baru dalam bentuk penyeragaman dan kepatuhan. Sistem pendidikan yang dijalankan oleh Orde Baru disebut W.S. Rendra sebagai "Mesin pendidikan yang tanpa visi"7. Sebagai orang Jawa yang juga seorang budayawan, W.S. Rendra memilih senjata yang paling ampuh untuk mengalahkan hegemoni

\footnotetext{
${ }^{7}$ Yang disebut dengan manipulasi ideologi Pancasila adalah Penggunaan ideologi Pancasila, namun isinya paham Kapitalis.. Sesat Pikir Teori Pembangunan dan Globalisasi. Yogyakarta: Insist Press, 2001.
}

pendidikan oleh kekuasaan yang terlalu kuat tanpa menimbulkan kegaduhan, yaitu melalui komunikasi politik dalam karya-karyanya. Pilihan tersebut dianggap sebagai "Nglurug tanpa bala, digdaya tanpa Aji, menang tanpa ngasorake. Itulah sebabnya, W.S. Rendra menyampaikan gagasan sistem pendidikannya melalui puisi, drama, dialog, dan pidato-pidato kebudayaan..

Gagasan sistem pendidikan W.S. Rendra adalah pendidikan yang berbasis riset, lingkungan, humanis, sejarah, dan kebudyaan sendiri. Melalui riset, pendidikan membiasakan peserta didik menghormati fakta objektif dan hukum alam. Melalui pemahaman potensi dan masalah di lingkungannya, pendidikan membiasakan peserta didik untuk belajar mengatasi masalah-masalah faktual yang ada di lingkungannya. Melalui pemahaman nilai-nilai humanis, pendidikan dapat melatih kepekaan peserta didik terhadap ketidakadilan dan kekerasan kemanusiaan. Melalui pemahaman sejarah, pendidikan dapat memberikan semangat nasionalisme 
dan menghargai pahlawan bangsa.

Melalui kebudayaan, pendidikan dapat mengokohkan kepribadian peserta didik dalam kebudayaan sendiri sehingga tidak mudah terprovokasi oleh kebudayaan dari luar.

Secara konsisten gagasan pendidikan disampaikan secara terusmenerus melalui karya-karyanya yang didedikasikan untuk bangsa dan negara demi terwujudnya kesadaran kolektif untuk terbangunnya peradaban yang harmonis dalam tata kehidupan berbangsa dan bernegara sesuai dengan nilai-nilai budaya bangsa dalam ideologi Pancasila ${ }^{8}$. Implikasi dalam Praktik penyelenggaraan pendidikan adalah kembalinya cita-cita kemerdekaan dalam preambul dan pasal 31 UUD 1945, yaitu "mencerdaskan" kehidupan bangsa, berupa pendidikan berbasis riset, potensi lingkungan, dan pendidikan karakter Pancasila. Pendidikan harus memberikan ruang gerak kepada guru dan peserta didik untuk berkreativitas, berinovasi, dan berkarya seluas-luasnya. Pendidikan harus membuat bangga menjadi anak
Indonesia. Dengan demikian, pendidikan dapat memberikan kontribusi yang optimal kepada negara dalam melaksanakan pembangunan peradaban melalui penyiapan sumber daya manusia yang siap membangun daerahnya, tangguh, kreatif, produktif, peka, dan berdaya saing global.

\section{DAFTAR PUSTAKA}

Chaniago, Andrinof A. 2012. Gagalnya Pembangunan: Kajian Ekonomi Politik terhadap Akar Krisis Indonesia. Jakarta: Pustaka LP3ES.

Claessen, H.J.M. dan Sukadiyo. 1987. Antropologi Politik. Jakarta: Erlangga

Djarot, Eros, dkk. 2006. Siapa Sebenarnya Soeharto. Fakta dan Kesaksian para Pelaku Sejarah G-30-S. Jakarta: Media Kita.

Fakih, Mansour. 2001. Sesat Pikir

Teori Pembangunan dan Globalisasi. Yogyakarta: Insist Press.

Foucault, Michel. 2002. Wacana Kuasa/Pengetahuan.

Diterjemahkan oleh Yudi Santoso. Yogyakarta: Bentang Budaya

Foucault, Michel.

2011.

Pengetahuan dan Metode, Karya-Karya Penting Foucault, Yogyakarta : Jalasutra.

\footnotetext{
${ }^{8}$ Dijelaskan pada Bab VI dan Bab VII Disertasi ini
} 
Gramsci, Antonio. 1986. Selections From Prison Notebooks.Eds. by Quintin Hoare and Geoffrey N.Smith. London: Lawrence and Wishart.

Haryono, Edi.2005.Membaca Kepenyairan Rendra.Yogyakarta:Kepel Press.

Koentjaraningrat. 1994. Kebudayaan Jawa. Jakarta: Balai Pustaka McGlynn, John H. et al. (red.). 2007. Indonesia in the Soeharto years; Issues, incidents and images. Jakarta: Lontar Foundation

Pilger, John, 2002, The New Rules of the World. London: Verso Press.

Rendra, W.S.

1983.

Mempertimbangkan Tradisi. Jakarta: Gramedia.

Rendra. W.S. 1983. Potret Pembangunan dalam Puisi. Jakarta: Pustaka.

Rendra. W.S. 1993. Orang-rang Rangkas Bitung. Yogyakarta: Bentang Int..

Rendra, W.S. 1995. Teks Pidato kebudayaan, Introspeksi Bangsa, di TIM.

Rendra, W.S. 2001. Renungan Dasar Kebudayaan. Yogyakarta. Kepel.

Rendra, W.S. 2008. Megatruh Kambuh: Teks Pidato Kebudayaan, Gelar Doktor HC oleh UGM. Yogyakarta: Senat UGM.

Saefulloh Fatah, Eep. 1998. Catatan Atas Gagalnya Politik Orde Baru. Yogyakarta: Penerbit: PT Pustaka Pelajar.

Saefullah Fatah, Eep. 2004. Mencintai Indonesia dengan Amal: Refleksi atas Fase Awal Demokrasi. Jakarta: Republika.
Sarjono, Agus R. 2001. Sastra dalam Empat Orba. Yogyakarta: Bentang. Soemanto, Bakdi. 2003. Rendra: Karya dan Dunianya. Jakarta: Grasindo.

Wood, Michael. 2013. Sejarah Resmi Indonesia Modern: Versi Orde Baru dan Para Penantangnya.. Yogyakarta Ombak Utama.

Yamin, M. 2011. Menggugat Pendidikan Indonesia: Belajar dari Paulo Freire dan Ki Hajar Dewantara. Yogyakarta: Ar-Ruzz Media

Rendra, W.S. 2004. Video WS Rendra saksi Ahli MK. https://www.youtube. com/watch? $v=U$ fo $4 \mathrm{NgcA} 6 \mathrm{WY}$

Rendra, W.S. 2004. Video 1--7 Dialog Kebudayaan Program Impact $Q$ Channel dipandu Peter Ghonta.https://www.youtube. com. 